\title{
Influence of Chemical Pre-treatments Nanotechnology Based Applied to the Al Sheet on the Roughness and Morphology of the Surface
}

Jaroslava Svobodová, Pavel Kraus

Faculty of Production Technology and Management, J. E. Purkyne University in Usti nad Labem. Pasteurova 3334/7, 400 01 Usti nad Labem. Czech Republic. E-mail: svobodova@fvtm.ujep.cz, kraus@fvtm.ujep.cz

The article deals with the analysis of the chemical pre-treatment influence based on nanotechnology on the roughness and morphology of the Al sheet surface. Experimental material is Al-Mg sheet on which were applied two variants of surface chemical pre-treatment. The first chemical pre-treatment variant is based on the application of zirconium passivating product intended for creating of nanomolecular coatings on the surface of metallic material. The second chemical pre-treatment variant consists in application of fluid single-component product for protection of the aluminium surface after previous application of zirconium nanopassivation. Within the experiment are prepared experimental samples, which are as the next included to the surface rougness measurement on the confocal laser microscope. Experimantal samples are further examined in the terms of morphology of the surface thus according to the form of exluded layers of the chemical products on the basic material surface on the laser confocal microscope and on the electron microscope.

Keywords: Nanotechnology, chemical pre-treatment, surface roughness, surface morphology, Al-Mg

\section{References}

[1] MICHNA, Š., et al. (2005). Encyklopedie hliníku, Adin Prešov, ISBN 80-89041-88-4.

[2] KUŚMIERCZAK, S., SVOBODOVÁ, J. (2012). Microscopic Evaluation of Protective Coating by Coated Sheets after Corrosion Load, pp. 151-157. Manufacturing Technology, Journal for Science, Research and Production, Vol. 12, No. 13, ISSN 1213-2489.

[3] ADHIKARI, S., UNOCIC, K. A., ZHAI, Y., FRANKEL, G. S., ZIMMERMAN \& FRISTAD. (2011). Hexafluorozirconic acid based surface pretreatments: Characterization and performance assessment. Electrochimica Acta. [online], roč. 56, č. 4, s. 1912-1924, [cit. 2013-07-01]. Dostupné z www: http://www.sciencedirect.com/science/article/pii/S0013468610009692.

[4] SVOBODOVÁ, J., KUŚMIERCZAK, S. (2014). Analýza poškození práškově lakované vrstvy po korozním zatížení. Strojírenská technologie, ročník XIX, číslo 2, s. 119 -125, ISSN 1211-4162.

[5] VŠCHT. (2013). Př́íprava a charakterizace titaničitanu barnatého sol-gel metodami. Laboratoř oboru chemie a technologie materiáli̊, [online], [cit. 2013-04-15]. Dostupné z www: http://www.vscht.cz/ach/pub/FRVS-LOCHTM-man.pdf.

[6] SVOBODOVA, J. (2014). SEM and EDS Analysis Used in Evaluation of Chemical Pre-treatment Based on Nanotechnology. Manufacturing Technology, Journal for Science, Research and Production, Vol. 14, No. 3, ISSN 1213-2489.

[7] NDREATTA, F., a kol. (2011). Development and industrial scale-up of $\mathrm{ZrO} 2$ coatings and hybrid organic - inorganic coatings used as pre-treatments before painting aluminium alloys. Progress in Organic Coatings, [online], roč. $72,1-2$, [cit. 2013-04-16]. Dostupné $\mathrm{z}$ www: http://www.sciencedirect.com/science/article/pii/S0300944011000294. 